\title{
Factors affecting the auditor independence in financial statements audit in Vietnam
}

\author{
Thi Hong Lam Nguyen ${ }^{a^{*}}$ and Thu Hoai Nguyen ${ }^{a}$
}

\begin{tabular}{l}
${ }^{a}$ Thuongmai University, Vietnam \\
\hline C H R O N I C L E \\
\hline Article history: \\
Received: July 28, 2020 \\
Received in revised format: \\
July 302020 \\
Accepted: September 6, 2020 \\
Available online: \\
September 6, 2020 \\
\hline Keywords: \\
Independence \\
Auditor \\
Vietnam \\
\end{tabular}

\begin{abstract}
A B S T R A C T
Financial information that meets the user's requirements must be accurate, sufficient, timely and reliable. Consequently, national laws and international auditing standards require the auditor to provide confidence in the audited financial information. To achieve this, the auditor independence must be ensured. The objective of this study is to identify factors affecting the auditor independence in financial statements audit in Vietnam. The identified factors are audit tenure; the provision of nonaudit services; economic dependence; employment with audit clients; competition within the external audit market; the risk to the auditor from the provision of poor-quality audit services, and the disclosure of financial relations. Data of the study were collected through a survey of auditor, audit firms and users of financial statements such as managers, investors, accountants, etc. The findings are the basis for proposing recommendations to more enhance the auditor independence and audit quality in financial statements in VietNam.
\end{abstract}

\section{Introduction}

Financial information that meets the needs of the user must be accurate, sufficient, timely and reliable. Consequently, national laws and international auditing standards require the auditor to provide confidence in the audited financial information. For an audit to be successful requires a lot of factors, in which audit quality can be considered as the most important factor. Auditors are the ones who directly verify and express opinions about the financial statements and they must have professional expertise and skills, must ensure compliance with the requirements of professional ethics (objective, integrity, independently and confidentially) to ensure that they have discovered misstatements in the financial statements and disclosed all of them. Thus, if competence may be a necessary condition, independence is taken into account a sufficient condition to make sure about audit quality. The capacity allows auditors to be ready to detect material errors within the financial statements while the independence will make sure that the auditor publishes (reports) these errors within the audit report. In 1991, independent audit was born in Vietnam. Up to now, a comparatively complete set of regulations, standards and related systems have been formed. However, in auditing activities, the audited financial statements of some companies still have errors, causing great impacts on investors, banks, etc. As of July 2020, Vietnam has 311 auditing firms with approximately 1,500 licensed auditors (published on the web: www.mof.gov.vn). Additionally to Big Four companies and large audit firms, there are also lots of small audit firms, so the audit quality is restricted. According to The summary report on audit service quality inspection of auditing firms of VietNam association of certified public accountants (VACPA), 2015 - 2019, there are about 20\% of audit firms that assessed per annum as unsatisfactory (published on the web: www.mof.gov.vn). These companies have not fully complied with the present Vietnamese auditing standards and have not complied with professional ethics during which the auditor's independence wasn't

* Corresponding author

E-mail address: honglam@tmu.edu.vn (T. H. L. Nguyen) 
ensured within the audit process (such as not performing well the rotation of auditors; didn't sign a commitment on independence with customers before auditing ....). Therefore, this study was carried to research auditor independence, specifically analyzing factors affecting auditor independence in financial statements audit. The research findings are considered because of the basis for proposing recommendations to ensure auditor independence and improve the quality of financial statements audit in Vietnam.

\section{Literature review}

In general, the concept of independence is understood as being objective, not dependent on external factors when making a decision or a certain opinion. However, the concept of independence is also understood differently when there are differences in culture, society, politics or field of activity. There are many different views on the auditor independence such as the ability to report the auditor's findings (DeAngelo, 1981a); objective attitude when performing audit and reporting (Bartlett, 1993); state of mind (AICPA, 1992) or freely perform work within authority without being under pressure from anyone (ISB, 2000) and other definitions. So, the auditor independence is the impartial and objective attitude of the auditor when performing the audit and announcing the audit report, reflected in both the auditor's thoughts and the perception of the auditor and the user of the financial statements, audit reports. Auditor independence has been assessed based on two aspects, that is, in fact and appearance. Independence in fact is a state of thinking that allows auditors to perform audits with objectivity, honesty and skepticism while independence in appearance requires avoiding situations that may cause users of the audit reports to suspect that the auditor may give an unbiased opinion. So, in fact, auditors need to be independent of any client they provide audit services and must show to third parties that the auditor can maintain impartiality in judgment and resist pressure from managers at client companies (Chrystelle, 2016). If the auditor isn't seen to be independent, users will have less confidence within the financial statements, and therefore the auditor's opinion on the company's financial statements is going to be of no value (Firth, 1980). Thus, the credibility of auditors depends not only in facts but also, even as importantly, on the perception of independence. Both actual also as perceived auditor independence are critical elements within the maintenance of public confidence in the auditing profession (Pany \& Reckers, 1980).

\section{Table 1}

The variables used in the study

\begin{tabular}{|c|c|c|c|}
\hline Variables name & The scale & Code & Bases for selecting variables \\
\hline \multirow{3}{*}{ Audit tenure (TK) } & Rotation of auditors (more than 3 years) & TK1 & \multirow{3}{*}{$\begin{array}{l}\text { Shockley, 1981; Beattie et al., 1999; Sinnett, 2004; } \\
\text { Abu Bakar et al., 2005; Al-Ajmi et al., 2011; Dart, } \\
\text { 2011; Omri \& Akrimi, 2015; Nguyen \& Ha, 2015 }\end{array}$} \\
\hline & Rotation of audit partners (more than 3 years) & TK2 & \\
\hline & Rotation of audit firms (more than 5 years & TK3 & \\
\hline \multirow{4}{*}{$\begin{array}{l}\text { The provision of } \\
\text { non-audit services } \\
\text { (DV) }\end{array}$} & $\begin{array}{l}\text { Auditing firms provides accounting, tax advisory, internal audit and } \\
\text { financial services to audit clients }\end{array}$ & DV1 & \multirow{4}{*}{$\begin{array}{l}\text { Reckers \& Stagliano, 1981; McKinley et al., 1985; } \\
\text { Beattie et al., 1999; Abu Bakar et al., 2005; Alleyne } \\
\text { et al., 2006; Salehi, 2009; Al-Ajmi et al., 2011; } \\
\text { Omri \& Akrimi, 2015; Nguyen \& Ha, 2015; Twaha } \\
\text { et al., } 2017\end{array}$} \\
\hline & $\begin{array}{l}\text { Provision of executive search and appointment services by } \\
\text { incumbent auditor }\end{array}$ & DV2 & \\
\hline & Non-audit services from incumbent $>=50 \%$ audit fee & DV3 & \\
\hline & Non-audit services from incumbent $>=25 \%$ audit fee & DV4 & \\
\hline \multirow{2}{*}{$\begin{array}{c}\text { Economic } \\
\text { dependence }(\mathrm{P})\end{array}$} & Income of partner depends on the retention of a specific client & P1 & \multirow{2}{*}{$\begin{array}{l}\text { Beattie et al., 1999; Craswella et al., 2002; Alleyne } \\
\text { et al., 2006; Omri \& Akrimi, 2015; Nguyen \& Ha, } \\
\text { 2015; Twaha et al., } 2017\end{array}$} \\
\hline & Income from one client $10 \%$ of total revenues of the firm & $\mathrm{P} 2$ & \\
\hline \multirow{3}{*}{$\begin{array}{l}\text { Employment with } \\
\text { audit clients }(\mathrm{QH})\end{array}$} & $\begin{array}{l}\text { The rank of the ex-auditor who } \\
\text { firm }\end{array}$ & QH1 & \multirow{3}{*}{$\begin{array}{l}\text { Imhoff, 1978; Koh \& Mahathevan, 1993; Parlin \& } \\
\text { Bartlett, 1994; Iyer \& Raghunandan, } 2003\end{array}$} \\
\hline & $\begin{array}{l}\text { The time lapse between auditing and working for a client firm (under } \\
3 \text { years) }\end{array}$ & QH2 & \\
\hline & $\begin{array}{l}\text { The time lapse between auditing and working for a client firm (over } \\
3 \text { years) }\end{array}$ & QH3 & \\
\hline \multirow{6}{*}{$\begin{array}{l}\text { Competition within } \\
\text { the external audit } \\
\text { market }(\mathrm{CT})\end{array}$} & Com & CT1 & \multirow{6}{*}{$\begin{array}{l}\text { DeAngelo, 1981; Shockley, 1981; McKinley et al., } \\
\text { 1985; Abu Bakar et al., 2005; Alleyne et al., 2006; } \\
\text { Al-Ajmi et al., 2011; Omri \& Akrimi, 2015; } \\
\text { Nguyen \& Ha, 2015; Twaha et al., } 2017\end{array}$} \\
\hline & Auditor's desire not to lose status by losing & $\mathrm{CT} 2$ & \\
\hline & Audit-fee discounting and low-b & $\mathrm{CT} 3$ & \\
\hline & Budget & CT4 & \\
\hline & Being & CT5 & \\
\hline & Smal & CT6 & \\
\hline \multirow{4}{*}{$\begin{array}{l}\text { The risk to the } \\
\text { auditor from the } \\
\text { provision of poor - } \\
\text { quality audit } \\
\text { services (RR) }\end{array}$} & Risk to auditor of disciplinary action by professional body & RR1 & \multirow{4}{*}{$\begin{array}{l}\text { Teoh \& Lim, 1996; Beattie et al., 1999; Abu Bakar } \\
\text { et al., 2005; Alleyne et al., 2006; Al-Ajmi et al., } \\
\text { 2011; Nguyen \& Ha, 2015; Twaha et al., } 2017\end{array}$} \\
\hline & Risk to auditor of loss of practicing certificate & RR2 & \\
\hline & Risk of damage to reputation of auditors from pub & RR3 & \\
\hline & Risk of litigation against auditor & RR4 & \\
\hline \multirow{3}{*}{$\begin{array}{l}\text { The disclosure of } \\
\text { financial relations } \\
(\mathrm{CK})\end{array}$} & Disclosure of non-audit service & CK1 & \multirow{3}{*}{$\begin{array}{l}\text { Beattie et al., 1999; Alleyne et al., 2006; Alajmi et } \\
\text { al., 2011; Omri \& Akrimi, 2015; Nguyen \& Ha, } \\
\text { 2015; Twaha et al., } 2017\end{array}$} \\
\hline & Disclosure of audit fees & CK2 & \\
\hline & Disclosure of non-audit fees & CK3 & \\
\hline \multirow{4}{*}{$\begin{array}{c}\text { The auditor } \\
\text { independence (DL) }\end{array}$} & Auditor has not familiarity involved with the client firm & DL1 & \multirow{4}{*}{$\begin{array}{l}\text { IFAC, 2001; The Independent Auditing Law of } \\
\text { VietNam, 2011; Beckett, 2013; The Standard of } \\
\text { Professional Conduct for Accountants and Auditors } \\
\text { of VietNam, } 2015\end{array}$} \\
\hline & Auditor has not financial interest in client & DL2 & \\
\hline & Professional independence when auditing & DL3 & \\
\hline & Auditors have certification of the independence when auditing & DL4 & \\
\hline
\end{tabular}


In Vietnam, independence is provided for in the Standard of Professional Conduct for Accountants and Auditors (2015) and Law in Independent Auditing (2011). Independence requires auditors when giving their opinions to be independent in fact and independence in appearance. The independence in appearance mainly stems from the professional ethics of the auditor while independence in fact is shown mainly through: financial; familiar; professional expertise. There have been many studies on the factors affecting auditor independence. Most of the studies on the auditor independence focused upon identifying the factors which potentially influence independence, and assessing their impact upon the independence in appearance since independence in fact is unobservable (e.g. Imhoff, Jr, 1978; Firth, 1980; Shockley, 1981; Dykxhoorn \& Sinning, 1982; Bartlett, 1993; Abu Bakar et al., 2005; Law et al., 2008; Omri \& Akrimi, 2015). Some studies also show the difference in perceptions and views of different groups of subjects: auditors, accountants, credit officers, loans, investors, etc. about these impact factors (Reckers \& Stagliano, 1981; Beattie et al., 1999; Alleyne et al., 2006; Al-Ajmi \& Saudagaran, 2011; Nguyen \& Ha, 2015). Based on the previous studies, we present the results of our investigation on variables used for the survey. Table 1 presents details of the variables.

\section{Research Methodology}

\subsection{Sample and data collection method}

The survey subjects of this study are auditors and auditing firms in Hanoi such as AASC, A \& C, AFC, Hung Vuong, etc. and users of financial statements in banks, export companies, trade companies, services companies, etc. The data collection is done through survey questionnaires. The questionnaire included Likert-type items (ranging from $1=$ "strongly disagree" to $5=$ "strongly agree") to measure 7 independent variables and the auditor independence - dependent variable. Based on the study of Hair et al. (2011), the minimum sample size is calculated: $5 \times$ the total observed variables. For multivariate regression analysis, based on Tabachnick \& Fidell (2007), the minimum sample size to achieve is calculated using the formula: $50+8 \times \mathrm{m}$ (m: number of independent variables). Thus, the minimum sample size guaranteed for the study is 145 in accordance with the requirements set out and ensures the representativeness of the whole. The study used a random sampling method to select the sample. The total number of votes issued via email and google docs in the study was 180 , and the number of valid votes was 163 (accounting for 90,5\%).

\subsection{Data analysis method}

In order to test the scale models and assess the model's suitability in practice, as well as analyze the impact of factors affecting the auditor independence in Vietnam, the research uses the Exploratory factor analysis (EFA) and regression analysis.

\section{Results and dicussion}

\subsection{The demographic characteristics}

Of the surveyed subjects, the percentage of auditors was $57.7 \%$, while the users of financial statements were $42.3 \%$. The age of the respondent is from 30 to 50 years old so that the knowledge and experience needed for the occupation. The auditors have a higher level of experience in auditing and accounting, with 26 members of the CPA, ACCA; while users have only 5 members of ACCA.

\subsection{Analysis the factors affecting the auditor independence}

Firstly, the study analyzed the reliability of the scales in the model by Cronbach's alpha coefficient. Nonconforming variables excluded from the scales are variables with a correlation coefficient of the total and/or have Cronbach's Alpha if Item Deleted is greater than the Cronbach's Alpha value of the scale. So, the variable QH3 was deleted because the total correlation coefficient $=0.218<0.3$. The value of other variables in the scales is highly reliable with the total correlation coefficient>0.3 and Cronbach's Alpha coefficient $>=0.7$. Thus, the items measuring the variables are considered acceptable and the instruments are accepted for the reliability test. After that, the research team checked whether the data are full conditions for analysis by KMO and Bartlett's tests or not. The scale is accepted when $0.5 \leq \mathrm{KMO} \leq 1$; Sig coefficient. $=0.000$ of the Bartlett test indicates that observed variables are statistically significant; The total extracted variance is $\geq 50 \%$ and the factor load factor $\geq 0.5$ proves the appropriate reliability for factor analysis.

- For independent variables

Table 2

KMO and Bartlett's Test ( $2^{\text {th }}$ time $)$

\begin{tabular}{lll}
\hline Kaiser-Meyer-Olkin Measure of Sampling Adequacy. & & .800 \\
Bartlett's Test of Sphericity & Approx. Chi-Square & 1537.547 \\
& df & 253 \\
& Sig. & .000 \\
\hline
\end{tabular}

Source: Analysis results from the author's research data 
The results in Table 2 show that the KMO coefficient equal to $0.5<0.800<1.0$ proves the conformity of the EFA model; Bartlett test value is significant for Sig. $=0.000$ indicates that the observed variables are correlated with respect to the total number of observations.

Table 3

Total Variance Explained $\left(2^{\text {th }}\right.$ time $)$

\begin{tabular}{|c|c|c|c|c|c|c|c|c|c|}
\hline \multirow[b]{2}{*}{ Component } & \multicolumn{3}{|c|}{ Initial Eigenvalues } & \multicolumn{3}{|c|}{ Extraction Sums of Squared Loadings } & \multicolumn{3}{|c|}{ Rotation Sums of Squared Loadings } \\
\hline & Total & $\%$ of & Cumulative \% & Total & $\%$ of Variance & Cumulative \% & Total & $\%$ of Variance & Cumulative \% \\
\hline 1 & 5.959 & 25.907 & 25.907 & 5.959 & 25.907 & 25.907 & 3.785 & 16.455 & 16.455 \\
\hline 2 & 2.467 & 10.728 & 36.635 & 2.467 & 10.728 & 36.635 & 2.570 & 11.175 & 27.629 \\
\hline 3 & 2.107 & 9.159 & 45.794 & 2.107 & 9.159 & 45.794 & 2.312 & 10.053 & 37.682 \\
\hline 4 & 1.735 & 7.543 & 53.337 & 1.735 & 7.543 & 53.337 & 2.189 & 9.519 & 47.201 \\
\hline 5 & 1.640 & 7.131 & 60.468 & 1.640 & 7.131 & 60.468 & 2.131 & 9.266 & 56.467 \\
\hline 6 & 1.206 & 5.245 & 65.713 & 1.206 & 5.245 & 65.713 & 1.663 & 7.229 & 63.696 \\
\hline 7 & 1.085 & 4.716 & 70.429 & 1.085 & 4.716 & 70.429 & 1.549 & 6.733 & 70.429 \\
\hline 8 & .741 & 3.223 & 73.652 & & & & & & \\
\hline 9 & .627 & 2.728 & 76.380 & & & & & & \\
\hline 10 & .597 & 2.598 & 78.977 & & & & & & \\
\hline 11 & .572 & 2.487 & 81.464 & & & & & & \\
\hline 12 & .539 & 2.344 & 83.808 & & & & & & \\
\hline 13 & .473 & 2.055 & 85.863 & & & & & & \\
\hline 14 & .437 & 1.900 & 87.764 & & & & & & \\
\hline 15 & .419 & 1.821 & 89.585 & & & & & & \\
\hline 16 & .417 & 1.811 & 91.396 & & & & & & \\
\hline 17 & .388 & 1.688 & 93.084 & & & & & & \\
\hline 18 & .335 & 1.458 & 94.542 & & & & & & \\
\hline 19 & .300 & 1.303 & 95.845 & & & & & & \\
\hline 20 & .268 & 1.164 & 97.009 & & & & & & \\
\hline 21 & 247 & 1.073 & 98.082 & & & & & & \\
\hline 22 & .225 & .978 & 99.060 & & & & & & \\
\hline 23 & .216 & .940 & 100.000 & & & & & & \\
\hline
\end{tabular}

Source: Analysis results from the author's research data

Then, performed the analysis of variance extracted of factors. Table 3 shows that the total variance extracted with the cumulative variance value of the factors is $70.429 \%>50 \%$ meeting the standard that means $70.429 \%$ of the variation of the data set is explained by 7 factors. The variable DV4 was excluded from the model due to this variable being uploaded by both factors (not guaranteed convergence and discrimination).

\section{Table 4}

Rotated Component Matrix ${ }^{\mathrm{a}}\left(2^{\text {th }}\right.$ time $)$

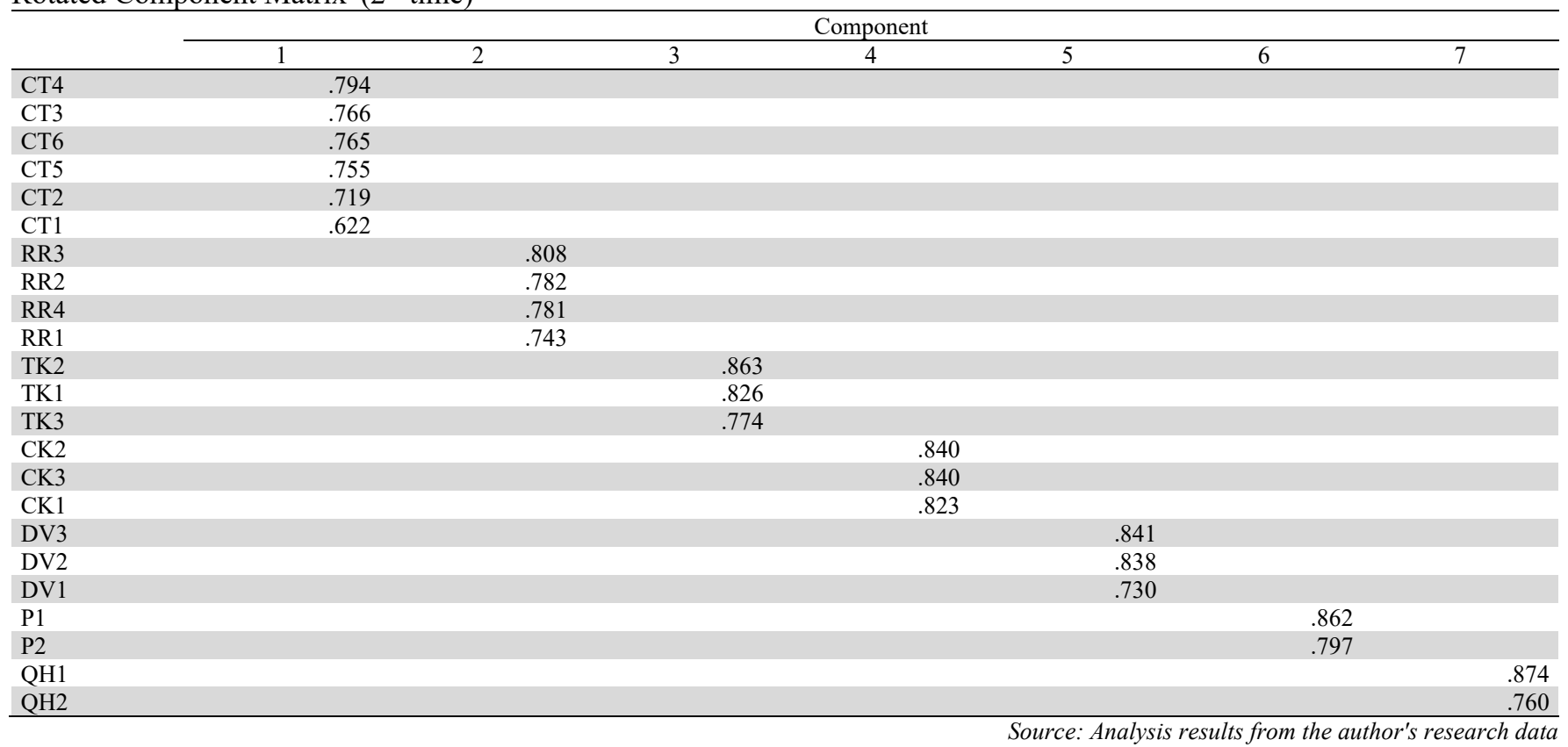

The results in Table 4 by using the rotation matrix show that there are 7 groups of factors drawn, including: 
The first group of factors is named the group of factors: "Competition within the external audit market (CT)". It consists of 6 observed variables: Competition among audit firms (CT1); Auditor's desire not to lose status by losing key client (CT2); Auditfee discounting and low-balling (price pressure) (CT3); Budget pressures imposed by audit firm on staff (CT4); Being a Big Four international firm or an international firm (CT5); Small, local audit firm (CT6);

The second group of factors is named the group of factors: "The risk to the auditor from the provision of poor - quality audit services (RR)". It consists of 4 observed variables: Risk to auditor of disciplinary action by professional body (RR1); Risk to auditor of loss of practicing certificate (RR2); Risk of damage to reputation of auditors from public scandals (RR3); Risk of litigation against auditor (RR4);

The third group of factors is named the group of factors: "Audit tenure (TK)". It consists of 3 observed variables: Rotation of auditors (more than 3 years) (TK1); Rotation of audit partners (more than 3 years) (TK2); Rotation of audit firms (more than 5 years) (TK3);

The fourth group of factors is named the group of factors: "The disclosure of financial relations (CK)". It consists of 3 observed variables: Disclosure of non-audit service (CK1); Disclosure of audit fees (CK2); Disclosure of non-audit fees (CK3);

The fifth group of factors is named the group of factors: "The provision of non-audit services (DV)". It consists of 3 observed variables: Auditing firms provides accounting, tax advisory, internal audit and financial services to audit clients (DV1); Provision of executive search and appointment services by incumbent auditor (DV2); Non-audit services from incumbent $>=50 \%$ audit fee (DV3)

The sixth group of factors is named the group of factors: "Economic dependence (P)". It consists of 2 observed variables: Income of partner depends on the retention of a specific client (P1); Income from one client 10\% of total revenues of the firm (P2);

The seventh group of factors is named the group of factors: "Employment with audit clients (QH)". It consists of 2 observed variables: The rank of the ex-auditor who accepts employment with a client firm (QH1); The time - lapse between auditing and working for a client firm (under 3 years) (QH2).

- For dependent variables

\section{Table 5}

KMO and Bartlett's Test

\begin{tabular}{lll}
\hline Kaiser-Meyer-Olkin Measure of Sampling Adequacy. & .797 \\
Bartlett's Test of Sphericity & Approx. Chi-Square & 271.284 \\
& df & 6 \\
& Sig. & .000 \\
\hline
\end{tabular}

Source: Analysis results from the author's research data

KMO and Bartlett's scale (Kaiser-Meyer-Olkin) with value $=0.797$ satisfies a condition that ranges from 0.5 to 1 ; the Bartlett's Test results have a Sig value. $=0.000$. Factor analysis is consistent with real data.

Table 6

Total Variance Explained

\begin{tabular}{|c|c|c|c|c|c|c|}
\hline \multirow[b]{2}{*}{ Component } & \multicolumn{3}{|c|}{ Initial Eigenvalues } & \multicolumn{3}{|c|}{ Extraction Sums of Squared Loadings } \\
\hline & Total & $\%$ of Variance & Cumulative $\%$ & Total & $\%$ of Variance & Cumulative $\%$ \\
\hline 1 & 2.711 & 67.781 & 67.781 & 2.711 & 67.781 & 67.781 \\
\hline 2 & .620 & 15.512 & 83.292 & & & \\
\hline 3 & .387 & 9.669 & 92.961 & & & \\
\hline 4 & .282 & 7.039 & 100.000 & & & \\
\hline
\end{tabular}

According to Table 6 , the total variance extracted with the cumulative variance value of the factors is $67.781 \%$, which means $67.781 \%$ chance of factors is explained by observed variables.After testing the reliability and analyzing EFA, the research team used Pearson's correlation coefficient to check the correlation between the dependent and independent variables. The result in table 7 shows that the Sig. value between each independent variable and the dependent variable is less than 0.05 so does not remove any type of factors. In other words, all the independent variables have a linear relationship with the dependent variable. To examine the impact of independent variables on the dependent variable, the study performs multivariate regressions. The results in Table 8 and Table 9 show that adjusted R Square $=0.694$, F-test (ANOVA) represents the significance level. $=0.000$; therefore, the regression model is suitable, about $69.4 \%$ of the variation of the dependent variable is explained by the independent variables in the model. 
Table 7

Correlations

\begin{tabular}{|c|c|c|c|c|c|c|c|c|c|}
\hline & & DL & TK & RR & $\mathrm{QH}$ & $\mathrm{CK}$ & $\mathrm{P}$ & DV & $\mathrm{CT}$ \\
\hline \multirow[t]{3}{*}{$\mathrm{DL}$} & Pearson Correlation & 1 & $-.507^{* *}$ & $.373^{* *}$ & $-.509^{* *}$ & $.339^{* *}$ & $-.594^{* *}$ & $-.500^{* *}$ & $-.611^{* *}$ \\
\hline & Sig. (2-tailed) & & .000 & .000 & .000 & .000 & .000 & .000 & .000 \\
\hline & $\mathrm{N}$ & 163 & 163 & 163 & 163 & 163 & 163 & 163 & 163 \\
\hline \multirow[t]{3}{*}{ TK } & Pearson Correlation & $-.507^{* *}$ & 1 & $-.189^{*}$ & $.243^{* *}$ & $-.189^{*}$ & $.236^{* *}$ & $.271^{* *}$ & $.313^{* *}$ \\
\hline & Sig. (2-tailed) & .000 & & .016 & .002 & .016 & .002 & .000 & .000 \\
\hline & $\mathrm{N}$ & 163 & 163 & 163 & 163 & 163 & 163 & 163 & 163 \\
\hline \multirow[t]{3}{*}{$\mathrm{RR}$} & Pearson Correlation & $.373^{* *}$ & $-.189^{*}$ & 1 & $-.292^{* *}$ & -.042 & $-.208^{* *}$ & $-.154^{*}$ & $-.236^{* *}$ \\
\hline & Sig. (2-tailed) & .000 & .016 & & .000 & .599 & .008 & .049 & .002 \\
\hline & $\mathrm{N}$ & 163 & 163 & 163 & 163 & 163 & 163 & 163 & 163 \\
\hline \multirow[t]{3}{*}{$\overline{\mathrm{QH}}$} & Pearson Correlation & $-.509^{* *}$ & $.243^{* *}$ & $-.292^{* *}$ & 1 & $-.179^{*}$ & $.344^{* *}$ & $.251^{* *}$ & $.414^{* *}$ \\
\hline & Sig. (2-tailed) & .000 & .002 & .000 & & .023 & .000 & .001 & .000 \\
\hline & $\mathrm{N}$ & 163 & 163 & 163 & 163 & 163 & 163 & 163 & 163 \\
\hline \multirow[t]{3}{*}{$\mathrm{CK}$} & Pearson Correlation & $.339^{* *}$ & $-.189^{*}$ & -.042 & $-.179^{*}$ & 1 & $-.199^{*}$ & $-.158^{*}$ & $-.209^{* *}$ \\
\hline & Sig. (2-tailed) & .000 & .016 & .599 & .023 & & .011 & .044 & .007 \\
\hline & $\mathrm{N}$ & 163 & 163 & 163 & 163 & 163 & 163 & 163 & 163 \\
\hline \multirow[t]{3}{*}{$\mathrm{P}$} & Pearson Correlation & $-.594^{* *}$ & $.236^{* *}$ & $-.208^{* *}$ & $.344^{* *}$ & $-.199^{*}$ & 1 & $.197^{*}$ & $.491^{* *}$ \\
\hline & Sig. (2-tailed) & .000 & .002 & .008 & .000 & .011 & & .012 & .000 \\
\hline & $\mathrm{N}$ & 163 & 163 & 163 & 163 & 163 & 163 & 163 & 163 \\
\hline \multirow[t]{3}{*}{ DV } & Pearson Correlation & $-.500^{* *}$ & $.271^{* *}$ & $-.154^{*}$ & $.251^{* *}$ & $-.158^{*}$ & $.197^{*}$ & 1 & $.263^{* *}$ \\
\hline & Sig. (2-tailed) & .000 & .000 & .049 & .001 & .044 & .012 & & .001 \\
\hline & $\mathrm{N}$ & 163 & 163 & 163 & 163 & 163 & 163 & 163 & 163 \\
\hline \multirow[t]{3}{*}{$\mathrm{CT}$} & Pearson Correlation & $-.611^{* *}$ & $.313^{* *}$ & $-.236^{* *}$ & $.414^{* *}$ & $-.209^{* *}$ & $.491^{* *}$ & $.263^{* *}$ & 1 \\
\hline & Sig. (2-tailed) & .000 & .000 & .002 & .000 & .007 & .000 & .001 & \\
\hline & $\mathrm{N}$ & 163 & 163 & 163 & 163 & 163 & 163 & 163 & 163 \\
\hline
\end{tabular}

Source: Analysis results from the author's research data

Table 8

ANOVA $^{\mathrm{a}}$

\begin{tabular}{llccccc}
\hline Model & & Sum of Squares & df & Mean Square & F & Sig. \\
\hline \multirow{2}{*}{1} & Regression & 50.036 & 7 & 7.148 & 53.512 & $.000^{\mathrm{b}}$ \\
& Residual & 20.705 & 155 & .134 & \\
\cline { 2 - 6 } & Total & 70.741 & 162 & & \\
\hline
\end{tabular}

Table 9

Model Summary

\begin{tabular}{lccccc}
\hline & & & & \multicolumn{3}{c}{$\begin{array}{c}\text { Std. Error of the } \\
\text { Model }\end{array}$} & $\mathrm{R}$ & $\mathrm{R}$ Square & Adjusted R Square & Estimate & Durbin-Watson \\
\hline 1 & $.841^{\mathrm{a}}$ & .707 & .694 & .36548 & 2.084 \\
\hline
\end{tabular}

Table 10 presents the result of the multiple linear regression as follows: The variables have an impact on the dependent variable because the Sig value in the t-test of each independent variable is less than 0.05 . Besides, the beta coefficients value of the factors: TK; DV; P; QH; CT is negative, beta coefficients value of the factors: RR; CK is positive.

Table 10

Coefficients $^{\mathrm{a}}$

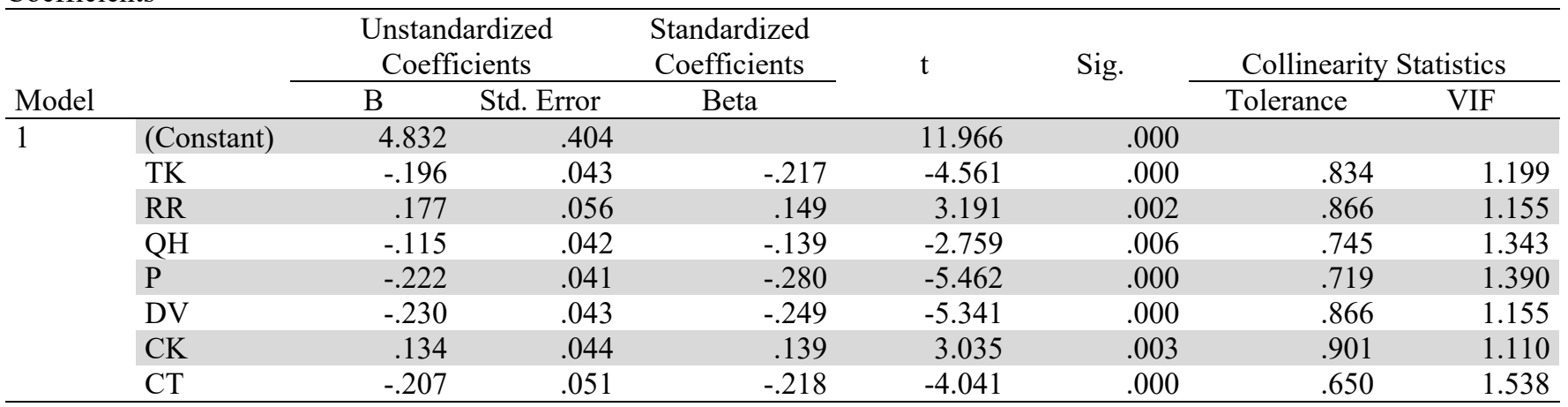




\section{Conclusion}

The results are consistent with the previous views when variables $\mathrm{CK}, \mathrm{QH}, \mathrm{RR}$ have little impact on the auditor independence (e.g. Salawu, 2017; Nguyen \& Ha, 2015; Al-Ajmi, 2011; Teoh et al., 1996; Koh \& Mahathevan, 1993; Imhoff, 1978) while other variables have a strong impact on the independence (e.g. Salawu, 2017; Omri \& Akrimi, 2015; Nguyen \& Ha, 2015; Alleyne et al., 2006; Abu Bakar, 2005; Beattie et al., 1999). At the same time, the variables TK; DV; P; QH; CT have negatively affected while the variables RR and CK have positive influences on the auditor independence. The findings show that to be able to ensure auditor independence so increase the quality of financial statement audit, have to perform the following:

Firstly, ensuring the rotation time of auditors and auditing firms; balancing non-auditing and auditing services for a client; disclosure of fees for services to reduce competition between auditing firm; regularly assess the risks to the auditor, auditing firm and control the audit quality, etc.

Secondly, more fully regulating the manifestations of independence in the legal documents and strictly implementing the signing of the commitment to independence before performing the audit.

This study has several limitations. The size of the survey sample and the scope of the survey are still limited, thus partly affecting the representativeness of the survey data. The study has not evaluated the impact level of factors from different groups of subjects. So, these limitations will be overcome by extensive research in future time.

\section{References}

AICPA (1992). Professional Standards. American Institute of Certified Public Accountants. New York.

Abu Bakar, N.B. Abdul Rahman, A., \& Abdul Rashid, H.M. (2005). Factors influencing auditor independence: Malaysian loan officers' perceptions. Managerial Auditing Journal, 21, 621-35

Accounting Professional \& Ethical Standards Board Limited (2008). Amendments to Auditor Independence Requirements in Section 290: Independence - Assurance Engagements of APES Code of Ethics for Professional Accountants. The Institute of Chartered Accountants in Australia

Al-Ajmi, J., \& Saudagaran, S. (2011). Perceptions of auditors and financial statement users regarding auditor independence in Bahrain. Managerial Auditing Journal, 26(2), 130 - 160

Alleyne, P.A., Devonish, D., \& Alleyne. P. (2006). Perceptions of auditor independence in Barbados. Managerial Auditing Journal, 21, 621-635.

Bamber, E. M., \& Iyer, V.M. (2007). Auditors' identification with their clients and its effect on auditor objectivity. Auditing: A Journal of Practice \& Theory, 26(November), 1-24

Bartlett, R.W. (1993). A scale of perceived independence: new evidence on an old concept. Accounting. Auditing \& Accountability Journal, 6(2), 52-67.

Beattie, V., Brandt, R., \& Fearnley. S. (1999). Perceptions of auditor independence: UK evidence. Journal of International Accounting. Auditing and Taxation, 8, 67-107.

Ference, S. B. (2013). Independence is in the eye of the beholder. Journal of Accountancy, 215(6), 18.

Canning, M, \& Gwilliam, D. (1999). Non-audit services and auditor independence: some evidence from Ireland. European Accounting Association, 8, 401-419.

Craswella, A., Stokesb, D.J., \& Laughton, J. (2001). Auditor independence and fee dependence. Journal of Accounting and Economics, 33, 253-275.

Chrystelle, R. (2006), Why an auditor can't be competent and independent: A French case study. European Accounting Review, 15(2), 153-179.

Dart, E. (2011). UK investors' perceptions of auditor independence. The British Accounting Review, 43(3), 173- 185.

DeAngelo, L.E. (1981). Auditor size and audit quality. Journal of Accounting and Economics, 3, 183-199.

Dykxhoorn, H. J., \& Sinning, K. E. (1982). Perceptions of auditor independence: Its perceived effect on the loan and investment decisions of German financial statement users. Accounting, Organizations and Society, 7(4), 337-347.

Firth, M. (1980). Perceptions of auditor independence and official ethical guidelines. The Accounting Review, 55, 451-66.

Gay, G., \& Simnett, R. (2003). Auditing \& Assurance Services in Australia. $2^{\text {nd }}$ ed. McGrawHill Book Australia Pty. Sydney

Hair, J. F., Ringle, C. M. \& Sarstedt. M. (2011). PLS-SEM: Indeed a silver bullet. Journal of Marketing theory and Practice, $19(2), 139-152$.

Hoyle, J. (1978). Mandatory auditor rotation: the arguments and an alternative. The Journal of Accountancy, 145(5), 69-78.

Imhoff Jr, E. A. (1978). Employment effects on auditor independence. Accounting Review, 53(4), 869-881.

ISB (2000). Statement of Independence Concepts: A Conceptual Framework for Auditor Independence. Exposure Draft ED 002. Independence Standards Board

Iyer, V. M. \& Raghunandan, K. (2003). Auditors' Employment with Clients and Interaction with their Former CPA Firm. Journal of Managerial Issues, 14(4).

Koh, H.C., \& Mahathevan, P. (1993). The effects of client employment on auditor independence. British Accounting Review, 25, 227-242 
Knapp, M.C. (1985). Audit conflict: an empirical study of the perceived ability of auditors to resist management pressure. The Accounting Review, 16, 202-211.

Law, P. (2008). An empirical comparison of non-big 4 and big 4 auditors' perceptions of auditor independence. Managerial Auditing Journal, 23(9), 917-934.

Salehi, M. (2009). Non-Audit Service and Audit Independence: Evidences from Iran. International Journal of Business and Management, 4(2), 142-152.

Salawu, M. K. (2017). Factors influencing auditor independence among listed companies in Nigeria: Generalized method of moments (GMM) approach. International Journal of Economics and Finance, 9(8), 191-203.

Nguyen, T.P.H., \& Ha, H.N. (2015). Factors affect to the auditor independence - Evidence in Vietnam. Journal of Economics and Development, 215, 33-42.

Omri, M.A., \& Akrimi, N. (2015). Factors affecting auditor independence in Tunisia: The perceptions of financial analysts. Journal of Finance and Accounting, 3(3), 42-49.

Pany, K., \& Reckers, P.M.J. (1980). The effects of gifts. discounts and client size on perceived auditor independence. The Accounting Review, 55, 50-61.

Partin, J. C. and Bartlett, R.W. (1994). Prior employment effects and independence in fact. Business \& Professional Ethics Journal, 13, 185-202.

Pong, C., Grout, P., Jewitt, I. \& Whittington, G. (1994). Auditor professional judgement': implications for regulation and the law. Economic Policy, 9(2), 307-352.

Reckers, P. M., \& Stagliano, A. J. (1981). Non-audit services and perceived independence: Some new evidence. Auditing: A Journal of Practice and Theory, 1(1), 23-37.

Shockley, R.A. (1981). Perceptions of auditors' independence: an empirical analysis. The Accounting Review, 55, 785-800.

Sinnett, W. M. (2004). Are there good reasons for auditor rotation?. Financial Executive, 20(7), 29.

SOX (2002). Sarbanes-Oxley (SOX) Act of 2002 by the 107th Congress of the United States. Securities and Exchange Commission. Washington, DC.

Tabachnick, B.G. \& Fidell, L.S. (2007). Using multivariate statistics (5th edition). Boston: Pearson Education.

Twaha, K.K., \& Stephen, K.N. (2017). Perceived auditor independence factors in Uganda. Makerere Business Journal, 13(2), pp 128-153

Teoh, H.Y., \& Lim, C.C. (1996). An empirical study of the effects of audit committees. Disclosure of non-audit fees. and other issues on auditor independence: Malaysian evidence. Journal of Accounting. Auditing \& Taxation, 5, $231-248$.

Vietnam National Assembly (2011). The Law on Independent Auditing. No. 67/2011/QH12, issued on 29/03/2011

Vietnam association of certified public accountants - VACPA (2015). E-book 1.11. Standard of Professional Conduct for Accountants and Auditors

Wooten, T.C. (2003). Research about Audit Quality. CPA Journal, 73(1), 48-64.

Website: $\underline{\text { www.mof.gov.vn }}$

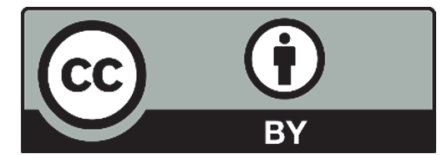

(C) 2020 by the authors; licensee Growing Science, Canada. This is an open access article distributed under the terms and conditions of the Creative Commons Attribution (CC-BY) license (http://creativecommons.org/licenses/by/4.0/). 